\title{
Clinical Students Perception towards the Care of HIV Positive Patients in Tertiary Hospitals, Bayelsa State, Nigeria
}

\author{
${ }^{1}$ Onasoga, Olayinka A; ${ }^{2}$ Azebri, Pereotubo Beauty; ${ }^{3}$ Otu, Edith; ${ }^{4}$ Atubo God's \\ Favour Emi \\ Department of Maternal and Child Health Nursing, Faculty of Nursing, Niger Delta University, Wilberforce \\ Island, Bayelsa State, Nigeria.
}

\begin{abstract}
HIV/AIDS is a global pandemic with greatest burden in sub-Saharan African including Nigeria which could be accounted for by wrong perception and poor care given to those with the disease. This is worrisome because poor perception today will result to poor care and patient's management outcome. This study was therefore aimed at perception of clinical students towards the care of HIV positive patients in tertiary hospitals, Bayelsa State, since they will eventually get into the work force and practice what they have been used to and this has serious implication on outcome of care and interventions on the patients. A descriptive cross sectional survey design involving questionnaires was used to obtain data from respondents over a period of Imonth. The target population consists of all clinical students in nursing, medicine and medical laboratory science. Purposive sampling technique was used to obtain a total of one hundred and twenty students who gave consent for the study. Data obtained were analyzed using the Statistical Package for Social Sciences (SPSS) windows version 20. Result indicates that almost all the students (89.2\%) showed positive perception in care of HIV/AIDS patients while few students (10.8\%) expressed negative perception in care of HIV/AIDS patients. Also, at $P<0.05$, Chi-square $\left(X^{2}\right)=12.437, D f=1$ and $P$-value $=0.000$, there was a statistical significant relationship between clinical students' perception and willingness to care for HIV/AIDS patients. Factors such as fear of contacting the infection, lack of facilities, lack of a definitive cure, lack of empathy and stigma associated with the disease were reported to influence perception of care of clinical students on HIV/AIDS patients. The need to promote positive perception on HIV/AIDS patient care becomes important.
\end{abstract}

Keywords: Care, Clinical students, Perception, HIV/AIDS, HIV positive, Patients

\section{Introduction}

HIV/AIDS has been declared the worse disaster to befall mankind in recorded human history and remains an issue of public health concern especially in developing nations where its health, economic and psycho-social implications are profound (Ike and Aniebue, 2007).

Human Immunodeficiency Virus is an infectious agent that causes acquired immunodeficiency syndrome (AIDS), a disease that leaves a person vulnerable to life-threatening infections (Redmond, 2009). No treatment is available that cures AIDS, but a number of drugs have been developed that suppress HIV replication, thereby preventing the destruction of the immune system. Six classes of antiretroviral drugs currently exist (Ritaburn, 2012). These drugs act at different steps in the replication of the HIV/AIDs virus. Nevertheless, there is increasing evidence that HIV and AIDs have diverse impact on individual life, family and the nation at large. Several burden of the disease have been reported. Among these are: health burden, higher demand for health care, economic burden, psychological burden, social stigma and poor educational outcome (Phelan, Link, and Meyer, 2008).

According to the UNAIDS (2011), HIV/AIDS is a global Pandemic and as of 2010, approximately 34 million people have HIV worldwide. Sub-Saharan Africa is the region most affected and in 2010, an estimated 68\% (22.9 million) of all HIV cases and 66\% (1.2 million) of all deaths occurred in this region; of which approximately 16.8 million are women and 3.4 million are less than 15 years old (UNAIDS 2011). Furthermore, Nigeria has the second-largest number of people living with HIV with a prevalence rate of $0.9 \%$ among adults aged 15-49 (CIA, World Fact Book, 2009). The HIV epidemic in Nigeria is complex and varies widely by region. In some states, the epidemic is more concentrated and driven by high-risk behaviors, while other states have more generalized epidemics that are sustained primarily by multiple sexual partnerships in the general population. Youth in Nigeria are particularly vulnerable to HIV, with young women at higher risk than young men.

Despite these high incidence in sub-saharan countries including Nigeria, poor care and attention towards HIV/AIDs patients has remain worrisome as people living with HIV/AIDs are often stigmatized and given poor attention especially in late stages of the disease (Phalen et al., 2008). 
According to UNAIDS (2006), HIV/AIDS patients are immunocompropmised and have higher demand for health care as the virus brings about a decline in their immune status leading to increased morbidity including those from opportunistic infections. Hence, their physical health is impaired and in order to remain a manageable state of health, constant medical check-up and care becomes inevitable and hence the need for increased hospital and health care visits.

HIV/AIDs is one of the most common stigmatized health conditions in every part of the globe especially in resource poor nations where the patients present late to hospital with full blown disease (Phelan et al, 2008; Yang, Cho and Kleinman, 2008). This has hitherto brought about poor perception towards care as often little or nothing can be done when some manifestations like HIV encephalopathy and nephropathy has set in as features of stage 4 disease. Such patients hardly survive and this has brought about wrong perception and poor care towards them among health care providers. This study aimed to determine the perception of clinical students on the care of HIV positive patients and the factors that influence their perception, since poor perception of care today will result to poor care and patient's management outcome. Hence, the perception of clinical students in nursing, medicine and medical laboratory is important as they will eventually get into the work force and practice what they have been used to as students.

\section{Methodology}

A descriptive cross sectional survey design was used and this study was carried out in the only two tertiary hospitals in Bayelsa State. These hospitals serve as institutions for training nursing, medical laboratory and medical students as well as other health professions in Bayelsa State. The target population consists of all clinical students in nursing, medicine and medical laboratory science that were on clinical posting in these hospitals at the time of the study. Purposive sampling technique was used for this study to obtain a total of one hundred and twenty students who gave consent for the study. The instrument used for this study was a selfstructured questionnaire. To ensure standard analysis of studied parameters, the statistical package for social sciences (SPSS) version 20.0 was used to analyze data from the study. Frequency and Percentage was obtained for descriptive statistics and test of significant relationship for studied variables was done using the Pearson's Chi-square $\left(\mathrm{X}^{2}\right)$ with level of significance set at $5 \%(0.05)$. A letter of authority seeking permission to undertake the study was issue to the hospitals and the purpose of the study was explained to the participants and a verbal consent was obtained. Also anonymity and confidentiality was assured.

\section{Results}

Table 1: Socio-Demographic Data of Respondents $(n=120)$

\begin{tabular}{|l|l|l|}
\hline Socio-demography & Frequency (f) & Percentage (\%) \\
\hline Age: & 21 & \\
$15-20$ & 78 & 17.5 \\
$21-25$ & 20 & 65.0 \\
$26-30$ & 1 & 16.7 \\
$31-35$ & & 0.8 \\
\hline Gender: & 32 & \\
Male & 88 & 26.7 \\
Female & & 73.3 \\
\hline Marital Status: & 103 & \\
Single & 16 & 85.8 \\
Married & 1 & 13.3 \\
Divorced & & 0.8 \\
\hline Course: & 63 & \\
Nursing & 26 & 52.5 \\
Medical Laboratory & 31 & 21.7 \\
Medicine & & 25.3 \\
\hline Level: & 14 & \\
200 & 21 & 11.7 \\
300 & 57 & 17.5 \\
400 & 28 & 47.5 \\
500 & 200 & 23.3 \\
\hline Religion: & & \\
Christian & & 100.0 \\
\hline
\end{tabular}

Table 1 shows the socio-demographic distribution of respondents: 21(17.5\%) were 15-20years, $78(65.0 \%)$ were 21 -25years, $20(16.7 \%)$ were 26 -30years, while $1(0.8 \%)$ are 31 -35years; $32(26.7 \%)$ were males while $88(73.3 \%$ ) were females; $103(85.8 \%)$ were singles, $16(13.3 \%)$ were married while $1(0.8 \%)$ is divorced; $63(52.5 \%)$ were in nursing, $16(13.3 \%)$ were in medical laboratory while $31(25.3 \%)$ were in medicine; $14(11.7 \%$ ) were in $200 \mathrm{~L}, 21(17.5 \%)$ were in $300 \mathrm{~L}, 57(47.5 \%)$ were in $400 \mathrm{~L}$ while $28(23.3 \%)$ were in $500 \mathrm{~L}$; all the respondents $200(100.0 \%)$ were Christians 
Table 2: Clinical Students' Perception of HIV/AIDS Patients Care $(\mathrm{n}=120)$

\begin{tabular}{|c|c|c|}
\hline Question/Statement & Frequency (f) & Percentage (\%) \\
\hline $\begin{array}{l}\text { Are you willing to take care of an HIV/AIDs patient? } \\
\text { Yes } \\
\text { No }\end{array}$ & $\begin{array}{l}111 \\
9\end{array}$ & $\begin{array}{l}99.2 \\
0.8\end{array}$ \\
\hline $\begin{array}{l}\text { Have you ever taken care of an HIV/AIDs patient? } \\
\text { Yes } \\
\text { No }\end{array}$ & $\begin{array}{l}110 \\
10\end{array}$ & $\begin{array}{l}91.7 \\
8.3\end{array}$ \\
\hline $\begin{array}{l}\text { Should HIV/AIDs patients be kept in isolation without any form of care? } \\
\text { Yes } \\
\text { No }\end{array}$ & $\begin{array}{l}1 \\
119\end{array}$ & $\begin{array}{l}0.8 \\
99.2\end{array}$ \\
\hline $\begin{array}{l}\text { Will you refuse caring for an HIV/AIDs patient if you are the one on duty/call? } \\
\text { Yes } \\
\text { No }\end{array}$ & $\begin{array}{l}7 \\
113\end{array}$ & $\begin{array}{l}5.8 \\
94.2\end{array}$ \\
\hline $\begin{array}{l}\text { Are you comfortable taking care of an HIV/AIDs patient? } \\
\text { Yes } \\
\text { No }\end{array}$ & $\begin{array}{l}53 \\
67\end{array}$ & $\begin{array}{l}44.2 \\
55.8\end{array}$ \\
\hline $\begin{array}{l}\text { Would you encourage a colleague to care for an HIV/AIDs patient? } \\
\text { Yes } \\
\text { No }\end{array}$ & $\begin{array}{l}96 \\
24\end{array}$ & $\begin{array}{l}80.0 \\
20.0\end{array}$ \\
\hline $\begin{array}{l}\text { Do you feel upset when caring for patients with HIV/AIDs? } \\
\text { Yes } \\
\text { No }\end{array}$ & $\begin{array}{l}14 \\
106\end{array}$ & $\begin{array}{l}11.7 \\
88.3\end{array}$ \\
\hline $\begin{array}{lllllllllll}\text { Do } & \text { you } & \text { show } & \text { empathy } & \text { in } & \text { caring } & \text { for } & \text { HIV } & \text { and } & \text { AIDs } & \text { patients? } \\
\text { Yes } & & & & & & & & & & \\
\text { No } & & & & & & & & & & \\
\end{array}$ & $\begin{array}{l}100 \\
20\end{array}$ & $\begin{array}{l}83.3 \\
16.7\end{array}$ \\
\hline $\begin{array}{l}\text { Should collection of blood and samples from HIV/AIDs patients be avoided during } \\
\text { care? } \\
\text { Yes } \\
\text { No }\end{array}$ & $\begin{array}{l}29 \\
91\end{array}$ & $\begin{array}{l}24.2 \\
75.8\end{array}$ \\
\hline $\begin{array}{l}\text { Perception Score: } \\
\text { Negative } \\
\text { Positive }\end{array}$ & $\begin{array}{l}13 \\
107\end{array}$ & $\begin{array}{l}10.8 \\
89.2\end{array}$ \\
\hline
\end{tabular}

Table. 2 shows clinical students' perception of HIV/AIDs patients care: 111(99.2\%) are willing to take care of HIV/AIDs patients while $9(0.8 \%)$ are not, $110(91.7 \%)$ have taken care of an HIV/AIDs patient before while $10(8.3 \%)$ have not, $1(0.8 \%)$ stated that HIV/AIDs patients should be kept in isolation without care while $119(99.2 \%)$ do not agree to that, $7(5.8 \%)$ will refuse taking care of and HIV/AIDs patients when on call while $113(94.2 \%)$ will not, 53(44.2\%) are comfortable in taking care of HIV/AIDs patients while 67(55.8\%) are not, 96(80.0\%) would encourage a colleague to care for HIV/AIDs patients while 24(20.0\%) will not, 14(11.7\%) feel upset in caring for HIV/AIDs patients while 106(88.3\%) do not, 100(83.3\%) show empathy in caring for HIV/AIDs patients while 20(16.7\%) do not, 29(24.2\%) stated that collection of blood and other samples from HIV/AIDs patients should be avoided during care while $91(75.8 \%)$ do not agree to that. Overall, 13(10.8\%) expressed negative perception towards HIV/AIDs patients care while 107(89.2\%) showed positive perception towards HIV/AIDs patients care.

Table.3: Students Response on Care of HIV/AIDs Patients $(\mathrm{n}=120)$

\begin{tabular}{|l|l|l|}
\hline Question/Statement & Frequency (f) & Percentage (\%) \\
\hline I will never care for HIV/AIDs patients? & & \\
Agree & 1 & 0.8 \\
Strongly Agree & 57 & - \\
Disagree & 62 & 47.5 \\
Strongly Disagree & - & 51.7 \\
Undecided & & - \\
\hline Care of HIV/AIDs patients should be by experienced personnel and not students? & 36 & 30.0 \\
Agree & 1 & 0.8 \\
Strongly Agree & 62 & 57.1 \\
Disagree & 20 & 16.7 \\
Strongly Disagree & 1 & 0.8 \\
Undecided & & \\
\hline I prefer to care for patients with other ailment apart from HIV/AIDs. & 17 \\
Agree & 22 & 14.2 \\
Strongly Agree & 47 & 18.3 \\
Disagree & 21 & 39.2 \\
Strongly Disagree & 13 & 17.5 \\
Undecided & & 10.8 \\
\hline
\end{tabular}

Table. 3 shows students response on care of HIV/AIDs patients: $1(0.8 \%)$ stated that he/she will not take care of an HIV/AIDs patients while 57(47.5\%) agreed they will take care and 62(51.7\%) strongly agreed that 
they will take care of such patients; 36(30.0\%) agreed that care of HIV/AIDs patients should be done by experienced personnel, $1(0.8 \%)$ strongly agreed while $62(57.1 \%)$ disagree, $20(16.7 \%)$ strongly disagreed and $1(0.8 \%)$ was undecided in this issue; $17(14.2 \%)$ agreed that they prefer to take care of patients with other ailments apart from HIV/AIDs, 22(18.3\%) strongly agree while 47(39.2\%) disagree, 21(17.5\%) strongly disagree and $13(10.8 \%)$ were undecided.

Table 4: Factors Influencing Care Towards HIV/AIDs Patients $(\mathrm{n}=120)$

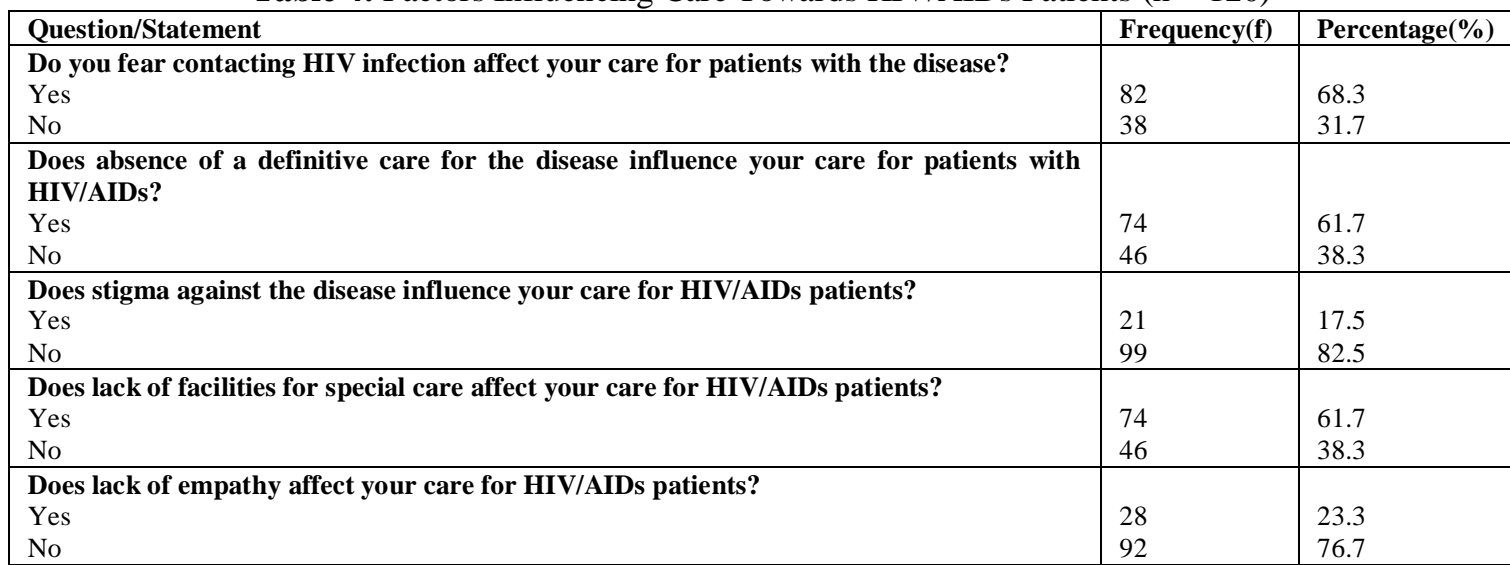

Table 4 shows factors influencing care of HIV/AIDs patients: 82(68.3\%) of the respondents reported fear of contacting the disease to influence their care for HIV/AIDs patients while 38(31.7\%) had a contrary view; 74(61.7\%) reported that absence of a definitive cure for the disease influence their care of HIV/AIDs patients while $46(38.3 \%)$ had a contrary view; $21(17.5 \%)$ reported that stigma associated with the disease influence their care of HIV/AIDs patients while the remaining 99(82.5\%) had a contrary view; 74(61.7\%) reported that lack of facilities for special care affect their care of HIV/AIDs patients while 46(38.3\%) stated that it does not; 28(23.3\%) reported that lack of empathy affect their care of HIV/AIDs patients while 92(76.7\%) stated that it does not.

Table 5: Relationship Between Clinical Students' Perception and Willingness to take care of HIV/AIDs Patients

\begin{tabular}{|c|c|c|c|c|c|}
\hline Variable & Perception & & Df & $\mathrm{X}^{2}$ & P-value \\
\hline & Negative & Positive & & & \\
\hline $\begin{array}{l}\text { Are you willing to take care of an } \\
\text { HIV/AIDs Patient }\end{array}$ & & & 1 & 12.437 & 0.000 \\
\hline Yes & 4 & 107 & & & \\
\hline No & 9 & 0 & & & \\
\hline
\end{tabular}

Table 5 shows the relationship between course of study and care for HIV/AIDs patients. At $\mathrm{P}<0.05$, Chi-square $\left(\mathrm{X}^{2}\right)=12.437, \mathrm{Df}=1$ and $\mathrm{P}$-value $=0.000$, there was a statistical significant relationship between clinical students' perception and willingness to care for HIV/AIDs patients.

Table 6: Relationship Between Course of Study and Perception of HIV/AIDs Patients Care

\begin{tabular}{llllll}
\hline Variable & Perception & & Df & X2 & P-value \\
\hline & Negative & Positive & & & \\
Course & & & 2 & 3.643 & 0.162 \\
Nursing & 4 & 59 & & & \\
Medical Laboratory & 5 & 21 & & & \\
Medicine & 4 & 27 & & & \\
\hline
\end{tabular}

Table 6 shows the relationship between course of study and Perception of care for HIV/AIDs patients. At $\mathrm{P}<0.05$, Chi-square $\left(\mathrm{X}^{2}\right)=3.643, \mathrm{Df}=2$ and $\mathrm{P}$-value $=0.162$, there was no statistical significant relationship between course of study and clinical students perception of care for HIV/AIDs patients.

\section{Socio-Demography}

\section{Discussion}

A total of one hundred and twenty $(n=120)$ with a mean age of 29.9 clinical students were involved in the study. Majority (85.8\%) are singles with more than half $(52.5 \%)$ in nursing department and almost half $(47.5 \%)$ in $400 \mathrm{~L}$ and all of them (100.0\%) were Christians. This finding implies that nursing students were more 
in the college and the clinical students are mostly in 400L. This is not surprising since nurses are the largest work force in the health care industries and most clinical students start their clinical in 400level except nursing

\section{Clinical Students' Perception Of HIV/Aids Patients Care}

The result from this study (Table 2) reveals that majority of the students have positive perception of HIV/AIDs patient care. Overall, $89.2 \%$ of the students showed positive perception while only $10.8 \%$ expressed negative perception towards HIV/AIDs patients care (Table 2). This is also, shown by their responses including almost all $(99.2 \%)$ of them stating that they are willing to take care of HIV/AIDs patients, out of which, 91.7\% \% of them have taken care of an HIV/AIDs patients before. Majority of the respondents stated that they will not refuse care of HIV/AIDs patients if they are on call. However, the remaining 5.8\% who stated that they will refuse care of an HIV/AIDs patients may constitute a problem to their health care facility as well as bring about discrimination and stigma to HIV//AIDs patients and thereby complicate their condition. Furthermore, despite the fact that majority stated that they are willing to take care of an HIV/AIDs patients as well as have taken care of an HIV/AIDs patients before, more than half of them $(55.8 \%)$ reported that they are not comfortable taking care of an HIV/AIDs patients. A reason for concern as work stress and serious errors can be made following administration of care to a patient that you are not comfortable with. Such discomforts, stems from stigma and discrimination associated with the disease and therefore needs to be addressed. A finding in consistent with Phelan et al., (2008) who stated that HIV/AIDs patients not only suffer from the illness, but also suffer from the problem of stigma and discrimination. The study also revealed that about a quarter $(24.2 \%)$ of the respondents will want to avoid blood and collection of samples from HIV/AIDs patients despite the majority (83.3\%) reporting that they will show empathy during care of such patients. Meaning that those who will not show empathy are students with stigma and discrimination associated with the disease.

\section{Care Of HIV/Aids Patients}

The result from this study (Table 3) indicates that almost all of the respondents stated that they will take care of HIV/AIDs patients. Also, about three quarter of the students (73.8\%) did not agree that care of HIV/AIDs should be confined to experienced personnel although some of them (32.5\%) will prefer to take care of patients with other ailment. This finding is reflective of the fact that most students will prefer to show care to other patients other than those with HIV/AIDs. A finding that may be attributable to fear of the disease, as it has no definitive cure as well as stigma associated with the disease

\section{Factors Influencing Care Of HIV/Aids Patients}

The result from this study reveals that an interplay of several factors influence the care of HIV/AIDs patients. Factors such as fear of contacting the infection, lack of facilities, lack of a definitive cure, lack of empathy and stigma associated with the disease were reported to influence perception of care of clinical students on HIV/AIDS patients. A finding that is similar to a study by Stavropoulou, Stroubouki, Lionaki, Bakogiogra and Zidianakis (2011), who also observed similar factors to influence the care of HIV and AIDs patients in Greece.

\section{Relationship Between Perception And Willingness To Care For HIV/Aids Patients}

The study showed that at $\mathrm{P}<0.05, \mathrm{X}^{2}=12.437, \mathrm{df}=1$ and $\mathrm{P}$-value $=0.000$, there was a statistical significant relationship between clinical students' perception and willingness to care for HIV/AIDs patients. This implies that the more positive the perception of clinical students in the care of HIV/AIDs, the more they will become willing to care for such patients and vice versa.

\section{Relationship Between Course Of Study And Clinical Students Perception Of HIV/Aids Care}

Table 5 shows the relationship between course of study and care for HIV/AIDs patients. At $\mathrm{P}<0.05$, $\mathrm{X}^{2}=3.643, \mathrm{df}=2$ and $\mathrm{P}$-value $=0.162$, there was no statistical significant relationship between course of study and clinical students perception of care for HIV/AIDs patients. This implies that despite the course, clinical students' perception of HIV/AIDs care is almost the same.

\section{Implication To Nursing}

HIV/AIDS is a global pandemic with serious implications and burdens profound in developing nations like Developing nations like Nigeria where care are often inadequate. Building better care in the future therefore depends on training nursing, medical and medical laboratory science students who will eventually become health care practitioners in the near future.

Their perception of care towards HIV/AIDS patients need to be positive and it requires the presence of the role models, educationist and counselors. The nurse fits in perfectly in this regards and therefore required not only to have adequate knowledge on HIV/AIDS but also show good perception towards care of the disease. 
Once this is realized, clinical students' perception will be sharpened and therefore better patient management at the moment and in the future

\section{Conclusion}

Proper care of HIV/AIDS patients eventually determine the health outcome and ability to cope with the various challenges associated with the disease.This study was designed to determine clinical student's perception of HIV/AIDS in tertiary hospitals, Bayelsa State. The result indicates that almost all the students (89.2\%) showed positive perception in care of HIV/AIDS patients while one student (10.8\%) expressed negative perception in care of HIV/AIDS patients. A statistical significant relationship was observed between perception and willingness of clinical students to care for HIV/AIDs patients.

Factors such as fear of contacting the infection, lack of facilities, lack of a definitive cure, lack of empathy and stigma associated with the disease were reported to influence perception of care of clinical students on HIV/AIDS patients. The need to encourage students to consider HIV/AIDS patients as every other patient as well expressed empathy was thereafter made.

\section{Recommendation}

1. Hospital management board should provide necessary facilities required for the care of HIV/AIDS patients

2. All health care workers should be taught on the need to be role models in the care of HIV/AIDS patients to students

3. Students should be encouraged to have positive perception and show empathy during care of HIV/AIDS patients.

[1]. CIA World Factbook, (2009).

\section{Reference}

[2]. Ike, S.O \& Aniebue, P.N. (2007) HIV/AIDS Perception and Sexual Behaviour among Nigerian University Students.Nigerian Journal of Clinical Practice. 10 (2): 105 - 110.

[3]. Phelan, J.C., Link, B.G \& Meyer, J,F. (2008). Stigma and prejudice: One animal or two? Social Science \&Medicine, 67, $358-367$.

[4]. Ratiburn, R. C., (2012): Antiretroviral therapy for HIV infection. Medscape reference, drugs, procedures and diseases, emedicine.com

[5]. Redmond,W.A. (2009); human Immunogenic clearly virus.Minessoft Encarta

[6]. Stavropoulou, A., Stroubouki, T., Lionaki, A., Lionaki, S., Bakogiorga, H., \&Zidianaski, Z. (2011): Student Nurses' Perception on Caring for People Living with HIV. Health Science journal, 5(4):288-292.

[7]. UNAIDS, 2011 'UNAIDS World AIDS Day Report 2011'

[8]. United Nations Programme on HIV/AIDS (UNADIDS) (2006). 2006 report on the global AIDS epidemic. Geneva, Switzerland: Joint United Nation's Programme on HIV/AIDS. http://www.org/dangkok.2006/report .html. Accessed on 10/11/07.

[9]. World Health Organization (WHO, 2005): Health promotion. WHO, Geneva.

[10]. Yang, L.H., Cho, S.H. \& Kleinman, A. (2008). Stigma of Mental Illness International Encyclopaedia of Public Health, $219-230$. 